\title{
Developing Partnership Based on Hospitable Schools for Children
}

\author{
Haromain \\ Institute of Teachers Training and Education Mataram, Indonesia \\ amaqalfi@gmail.com
}

\begin{abstract}
Inclusive education as the embodiment of education for all in the process must be supported by a safe and comfortable environment for every student. Children with special needs as learners in inclusive schools need a hospitable environment for the development of their motivation and self-esteem. Schools should prepare these hospitable environment for children needs through a partnership strategy built between schools, parents and the community. The objective of the study is to describe the school strategy in preparing a school environment that is hospitable to children with special needs that are focused on school policies and forms of partnerships that schools build in creating a hospitable environment for children. The research was conducted through qualitative approach with case study design at SDN 20 Mataram West Nusa Tenggara Province, Indonesia. The result of the research shows that: (1) the formulation of hospitable school for children environment policy is done through requirement analysis phase, policy formulation, and socialization of hospitable school for children environment policy; and (2) the form of school partnerships such as parent education, the establishment of parent community, the optimization of school communication, parents and community, strengthening school network, involving religious leaders and community leaders in school activities, utilization of facilities provided by the community for school activities.
\end{abstract}

Keyword: children with special needs, inclusive schools, schools partnership

\section{INTRODUCTION}

Education for all is the effort of the government to fulfill the right of the community to get the proper education. The access of the proper education is not only meant to those who has perfect physical and or social. The universal declaration of Human Rights in 1948 emphasis on the basic right of each individual to get the proper education without concerning on their background. However, Children with Special Needs recently does not get their proper education as it is aimed, it is because people's minimum understanding of their existence.

One of the government's effort to fulfill the right of these Children with Special Needs (CSN) to get the proper education by providing the educational services to special schools or extraordinary schools. Yet, the existence of the extraordinary schools is still limit and still focus in the city which is still not cover the CSN's necessity especially those who lived out of the city.

The inclusive schools become the alternatives for the fulfillment of the CSN's necessity who are not able to access the proper education in extraordinary schools. The inclusive schools is the schools where all the children can get in it, every children's needs is not only tolerated, but also it is being accommodated and fulfilled (Watterdal, 2002). The government through its Ministry of National Education release the regulation on Number 70 Year 2009 about the Inclusive Education for Children, who has abnormalities and who has potential intelligent and or special talent. It emphasize that the local government of district / city guarantee the implementation of the inclusive education based on the students' needs.

Schools as the second house of the children should give the proper place for the development of personality or social to each student. Hospitable environment for children is the requirements which should be fulfilled by the school organizer of the inclusive education in order to build the motivation and confidences of the CSN. These are the responsibilities of the schools, parents and the community in order to create the inclusive society that can accept the differences without seeing the abnormalities or special talent owned by the children. The stakeholder participation is much needed as a mean of attention on the implementation of the inclusive education at schools especially on adjustment and modification the support components to make it relevant with the local context, hospitable environment, and flexible to all children.

The resources limitation becomes the obstacles in creating the hospitable environment especially for the CSN. The limitation is in teachers' limitation on giving services for the CSN because of their minimum understanding to treat them. These affect the optimization of implementation of the inclusive education at school.

Other obstacles frequently faces by the CSN at school is the view of most people at the schools towards them, they assume that the CSN should be placed on special schools which handle their disabled or special talent they had. Therefore, it makes their assumption that the special needs children will always be different to others either in the learning process in class or other social interactions.

The successfulness in educating the CSN at inclusive school is, one of it, is affecting by the teacher's positive attitude on the learning process. When the teacher has positive expectation on pushing the children by giving them chance to learn and to strengthen their effort for the CSN then they will be able to continue their study. (Berry 2006) on his research, found that the effective inclusive class is sourced from the belief owned by teacher about the trust and the protection to improve students' academic achievement.

One important thing that should be understand is the acceptance on the differences of the special needs children can help them to feel comfortable and attempted to improve their skills. The availability of these hospitable environment for special needs children will give positive impact to their basic-skill development. The exploration of their basic-skill will be optimal when they are feeling comfortable on their environment; either in their house or in the schools 
This research aimed at getting the picture of school's strategy in developing partnership based of hospitable schools for children which focused on formulating the policy of hospitable schools for children, and the form of partnership between the schools, parent and the community.

\section{METHODS}

This research used qualitative approach by case study design at SDN 20 Mataram, West Nusa Tenggara which focused on formulating the policy of hospitable school for children and the form of partnership developed by the school, parent and the community on preparing hospitable school for children. This school is selected because it is one of the regular school that provide inclusive education by total 70 special needs children out of 224 students.

In this research, the researcher is the key instrument that doing direct observation and analyze the data into words, analyze the attitude and the policy that relate to the research focus at the school as the research object. Deeper analysis is done on the schools' strategy in developing partnership based of hospitable school for children which cover formulating school's policy consisting of the needs analysis, formulating the policy and the socialization of hospitable schools for children, and the form of partnership which developed by the school, parent and the community.

The data of the research is obtained through deeper observation on each process in the school environment, interview with the school's committee; Headmaster, teachers, parents of students, students and the people around the school. Besides, documents, scripts as well as notes about the partnership strategies developed by the school to prepare the hospitable environment for children become the information source for the researcher.

The data analysis begin since or during the data collection process, it is after collecting the data repeatedly. Ulfatin (2013) stated that the data analysis process are: (1) noted the field note; (2) giving the code so that the data source can be traced, collecting, sorting and classifying the data; (3) synthesizing, making the summary, making the index; (4) classifying and categorizing so that the data has a point; (5) seeking and finding the link pattern; and (6) making the research finding.

\section{RESULT}

The Public Elementary School (Sekolah Dasar Negeri) 20 Mataram is one of the 16 inclusive schools in Mataram, West Nusa Tenggara. Practically, this schools has established the inclusive school long time ago. It is seen from the number of the CSN, there are 70 children out of 224 students in 2016. The CSN students are vary, seen from the needs they are: blind, mentally disabled, unsociable, aqueduct, etc.

The CSN in this school are dominated by the children of local government officer; Mataram City officer and West Nusa Tenggara Provincial officers and the people around the school. The geographical place of the school that close to the local government office is the reason the school is chosen as the alternatives for their children to study. Besides, this school has the best services for the special needs children compare to other schools in Mataram. In 2015 this school is appointed as one of the pilot project school on the implementation of inclusive education in West Nusa Tenggara representing Mataram.

Before providing the appropriate services for the special needs children SDN 20 Mataram doing the assessment on their needs. They are: (1) forming the team consist of Headmaster, teachers, parent, psychologist and the institution representatives out of the inclusive schools (SLB Kota Mataram) to analyze the necessity of the CSN; and (2) identifying the types of the CSN necessity services.

From the analysis results then the school formulating the policy to give proper services for the CSN. In formulating the policy, headmaster with its team used the analysis results as the reference in taking the decision to which programs that become the priority for the CSN necessity services. Programs developed are based on school's capability especially the teachers, schools facilities, curriculum, financing and school's environment. The capabilities of the teachers; either its quantity or its quality are much affecting the achievement of the arranged program

The huge number of the CSN compare to the limited teachers encourage the school to cooperate with the CSN parent in the learning process. It is to ease the children to understand the learning and also not to disturb the learning process of other students.

The programs for the CSN then socialize to schools components. The process of socialization program is applied through activities within as well as beyond the school. Flag ceremony, Religious feast day, student's parent meeting, IMTAQ and other activities are targeted to socialize the hospitable environment program for the children.

In implementing those policies, SDN 20 Mataram optimizing their resources. Partnership with parents and the community is one of the effort of the school to ease the process of developing hospitable school for children. In process, there are some strategies of this partnership, they are: 1) Educating parent, 2) forming the students' parent community, 3) optimizing schools, parent and the community communication, 4) strengthening schools network, 5) religious and public figure engagement in curricular and extracurricular activities, 6) Utilization the facilities provided by the community for schools activities.

The partnership of parents and SDN 20 Mataram in giving the correct understanding on how to treat the CSN become the priority of the school, because they are the closest one to them at home. Giving the correct understanding to treat the CSN involve the parent of the CSN itself, by inviting them to school to give the information about the strategies for parent to serve their children. In this case, the school invite the psychologist to give the course of childrens development especially the CSN. Besides, the school is also cooperate with the extraordinary school (SLB Kota Mataram) to gain the knowledge of the CSN handling at home and at school. 
The partnership between schools and parent then strengthened by forming the community between students' parent. This community formed in every class to gain the information of their children activities and progresses. Every information relate to students' activities and progresses are informed to students' parent through this community. At the end of the semester, every students' parent are invited to get informed their children progress during the semester. While, for the CSN's parent they will informed their children's progress in every three months.

In creating the hospitable environment for children, SDN 20 Mataram optimize their network neither the local government as the institution in charge for the inclusive education nor the parent and the citizen around the schools. Communication in each components of the community is the key to accept the $\mathrm{CSN}$ in the middle of the community. In this case, the school frequently asked opinion to elders or public figures in the community to create hospitable environment for children. Moreover, the CSN's parent often asked to share their experience to handle the CSN to other parent.

As the responsibility to the community, SDN 20 Mataram optimize their network through their activities in school. Besides, to increase the CSN's confidences they are often involved in the competition held by the government institution or by the citizen around the school. It aimed to increase the awareness of the community of their existence as part of the community.

\section{Formulating the Policy}

\section{DISCUSSION}

Inclusive school as a form of implementation of inclusive education is essentially inseparable from the role of each component of the center of education taught by Ki Hajar Dewantara. Schools, parents and the community have their own roles in the character formation of students, especially the CSN. Limitations of abilities possessed by the CSN in adjusting to its environment require assistance from outside the child's self. In this limited condition, the role of each component of the center of education becomes very important.

Schools as formal institutions should be able to instill values of diversity to every citizen of the school. School committees, principals, teachers, parents and communities should have the same view of the education they want to build. Positive values that will be devoted to children should reflect diversity, especially the acceptance of differences in the capacity and independence of the CSN. These values of acceptance will be the initial capital for the formation of a child character that will be integrated into his daily life.

Similarly with the CSN who in their daily tend to have limitations in the process of interaction with others, it becomes a must for security and comfort so that the motivation and self-confidence will be formed perfectly. They will feel appreciated when their special deficiencies or talents are not at issue in the process of social interaction
As a first step in setting-up hospitable school for special needs children, needs assessment is crucial for the right services to be delivered. Astin (1993) states that the assessment as a collection of information relating to the function of students, teachers, and schools that aims to improve the performance of institutions and members in it.

The ideal assessment will be able to support talent development for students, teachers and schools. Without assessments, schools will find it difficult to formulate policies for hospitable environment for special needs children and may or may not provide services or mistreatment to them.

The results of the assessment on the needs of the CSN are used as the basis for the formulation of the principal's policy in preparing a hospitable environment for the CSN. The CSN hospitable environmental policy is further disseminated to every component of school both teachers and students

\section{The form of Partnership of the Schools, Parent and the community.}

The cooperation between the three centers of education in building the school environment is crucial to the successful achievement of inclusive education objectives. Schools should be the driving force of this cooperation as a form of open access to information to stakeholders. In this partnership, the role of each component must be optimized to support the educational process taking place in the school. Building a hospitable schools for children is not only the responsibility of the school as a formal institution, but the parents and the community also have the same responsibility

Awareness of open access to appropriate education for Children with Special Needs must be owned by parents and the community because education is not just the responsibility that should be burdened to the school alone. Partnerships built by schools can be formal partnerships and informal partnerships. Formal partnership is a form of cooperation based on an agreement or agreement that is binding and set forth in the documents together.

While informal partnership is a form of partnership based on non-binding agreements and not poured in the document of cooperation, but more as a form of cooperative, togetherness and mutual respect and respect the existence of their respective institutions Schools as a motor of this partnership should be able to provide access to information relating to all school activities so as to support the establishment of a comfortable environment conditions for each student.

Education for parents about services for the CSN and the establishment of parent community of students to be one of the school efforts in establishing intense communication about the procedures to provide services to children and the development of students, especially the CSN. Understanding parents who are sometimes inappropriate in treating their children (CSN) need to be improved through activities related to parent education and discussions among the parent community of students 


\section{CONCLUSION}

Building a hospitable school for children is essentially an effort to provide a sense of security and comfort for every student to gain his or her rights in education. A hospitable environment for children is the responsibility of every component of school, parents and society. The role of each component in building a hospitable environment for children is tailored to the functions and responsibilities attached to it. To build a hospitable environment for children, school policies and cooperation are needed based on awareness and awareness of the importance of education for each child by looking at the level of special needs or talents they had.

The formulation of policies on hospitable school for children is based on the results of needs analysis of the environmental conditions required to support the exploration of motivation and self-confidence of the Children with Special Needs. The policy that has been decided subsequently is socialized to be implemented to all components of the school, parents and community. Intense collaboration between schools, parents and the community will be the determinant for the success of the expected goals.

Education for parents, establishment of parent community, optimizing school communication with parents and community, strengthening school network, involving community leaders in school activities and utilization of public facilities for school activities become an integral part of the process of achieving educational goals in school. Acceptance of the condition of the Children with Special Needs shall be opened so that their existence as a part of society is acceptable to everyone regardless of the shortcomings or special talents it possesses.

\section{REFERENCES}

[1] Astin, W. A. 1993. Assesment for Excellence. The Philosophy and Practice of Assesment and evaluation in Higher Education. American Council on Education/Oryx Series on Higher Educatin. Maxwell Macmillan Internatonal.

[2] Berry, R. A. W. 2006. Inclusion, Power, and Community: Teachers and Students Interpret The Language of Community in an Inclusion Classroom. American Educational Research Journal, 43, 3, 489529.

[3] Hasyim, Y. 2013. Pendidikan Inklusif di SMK Negeri 2 Malang. Jurnal Kebijakan dan Pengembangan Pendidikan, 1(2), 112-121.

[4] Katz, J. \& Mirenda. P. 2002. Including Students With Developmental Disabilities in General Education Classrooms: Social Benefits. International Journal of Special Education, 17(2), 1-12.

[5] Olsen, G. \& Fuller, M. 2003. Home School Relation. Working Sucessfully with Parents and Families. Boston: Allyn and Bacon.

[6] Sonhadji. 2014. Asesmen Kebutuhan, Pengambilan Keputusan dan Perencanaan. Matarantai dalam Manajemen Pendidikan. Malang: State University of Malang.

[7] Ulfatin, N. 2013. Metode Penelitian Kualitatif di Bidang Pendidikan: Teori dan Aplikasinya. Malang: Bayumedia Publishing.
[8] UNESCO. 2000. Education for All: Meeting Our Collective Commitments. Text Adopted by the World Education Forum, Dakar, Senegal, 26-28 April. Retrieved December 3, 2016, from http://www.unesco.org/education/efa/ed_for all/dakfram eng.shtml.

[9] Watterdal, T. 2002. Inclusive Education in Indonesia. Jakarta: Braillo Norway. 